\title{
Essential Metals and Trace Elements in Cereals and Their Derivatives Commercialized and Consumed in Cape Verde
}

\author{
Carmen Rubio-Armendáriz ${ }^{1}$ Ángel J. Gutiérrez ${ }^{1}$. Verena Gomes-Furtado ${ }^{2} \cdot$ Dailos González-Weller $^{1,3}$. \\ Consuelo Revert ${ }^{4} \cdot$ Arturo Hardisson $^{1} \cdot$ Soraya Paz ${ }^{1}$ (I)
}

Received: 16 November 2021 / Accepted: 10 February 2022 / Published online: 28 February 2022

(c) The Author(s) 2022

\begin{abstract}
Cereals and their derivatives are basic foods in the human diet and a source of minerals, but the content of elements may vary depending on the type of cereal or its processing. The levels of $\mathrm{Na}, \mathrm{K}, \mathrm{Ca}, \mathrm{Mg}, \mathrm{Fe}, \mathrm{Cu}, \mathrm{Zn}, \mathrm{Mo}, \mathrm{Co}$, and $\mathrm{Mn}$ have been determined in 126 samples of cereals and cereal derivatives (rice, corn gofio, corn flour, wheat flour, corn, and wheat) commercialized and consumed in Cape Verde using an inductively coupled plasma-optical emission spectrometer (ICP-OES) after a wet microwave digestion process. Some elements stand out in products such as corn gofio $(\mathrm{K})$, wheat $(\mathrm{Mg})$, and wheat flour $(\mathrm{Fe})$. Negative correlations were found between Mo-Na and Na-Zn that could suggest interference between these elements. Bearing in mind the dietary intake evaluation and the guideline values provided by EFSA (European Food Safety Authority) or FAO (Food Authority Organization), the consumption of wheat (100 g/day) provides a notable contribution of $\mathrm{Mo}, \mathrm{Mn}, \mathrm{Fe}$, and $\mathrm{Mg}$. Considering the nutritional value of the analyzed essential and trace elements, the consumption of different cereals and their derivatives should be promoted.
\end{abstract}

Keywords Cereals $\cdot$ Cereal derivatives $\cdot$ Essential elements $\cdot$ Trace elements $\cdot$ Dietary intake $\cdot$ Cape Verde

\section{Introduction}

Cereals have been a staple foodstuff in the human diet for more than 10,000 years. Nowadays, the most consumed cereals worldwide are wheat, rice, corn, barley, oats, and rye. These are used in the production of daily consumption products such as bread, cookies, pasta, and drinks. Global cereal production is now almost three billion tons according to data collected by the FAO (Food and Agricultural Organization) [1]. However, the nutritional value of cereals is affected

Carmen Rubio-Armendáriz spazmont@ull.edu.es

Soraya Paz spazmont@ull.edu.es

1 Department of Toxicology, Universidad de La Laguna, La Laguna, Tenerife, Canary Islands, Spain

2 Independent Health Regulatory Authority, Av. Cidade de Lisboa, Praia, Cape Verde

3 Health Inspection and Laboratory Service, Canary Health Service, S/C de Tenerife, Tenerife, Canary Islands, Spain

4 Department of Physical Medicine and Pharmacology, University of La Laguna, Tenerife, Canary Islands, Spain by various factors such as soil quality, water composition, crop rotation, or the use of growth promoters. Therefore, the determination of the nutrient content in cereals, such as essential elements, is necessary to know their dietary intake.

The population of Cape Verde in 2020 was 555,988 inhabitants, and the nutritional status of the population has been previously evaluated and monitored [2-5]. According to data from the Ministry of Health and Social Security of the Government of Cape Verde, $11 \%$ of children under 5 years of age suffer from chronic malnutrition [3]. The latest data show that $37.7 \%$ of households in Cape Verde do not have economic access to safe, nutritious, and sufficient food [3] and $4.5 \%$ of children under 5 suffer from acute malnutrition [3]. At the national level, 52.7\% of households have moderate to low diversity in their diet, but this includes the cereal group [2,3] with a consumption of 84,820 tons in 2020. In Cape Verde, 84,000 of the 403,000 hectares of surface area are used for agriculture, and corn is one of the main crops grown on the islands [1]. In 2020, corn consumption was 30,157 tons (almost $150 \mathrm{~g} /$ day per citizen). Corn is the base ingredient of several traditional dishes in Cabo Verde, such as "cachupa, cherém, couscous, and camoca." Rice is the second most consumed cereal (25,996 tons, 
almost $120 \mathrm{~g} /$ day per citizen) followed by wheat $(16,907$ tons, around $80 \mathrm{~g} /$ day per citizen) and wheat flour $(11,760$ tons, around $60 \mathrm{~g} /$ day per citizen) $[6,7]$.

Cereals and their derivatives are valued for their content of both major elements or macro elements $(\mathrm{Na}, \mathrm{K}, \mathrm{Ca}$, $\mathrm{Mg}$ ) and trace elements ( $\mathrm{Fe}, \mathrm{Cu}, \mathrm{Zn}, \mathrm{Mo}, \mathrm{Co}, \mathrm{Mn})$. Macro elements $(\mathrm{Ca}, \mathrm{Mg}, \mathrm{K}, \mathrm{Na})$ are required by humans in high quantities for proper body functioning. $\mathrm{Ca}$ is an element in bone tissues. $\mathrm{K}$ and Na play a role in maintaining osmotic pressure and in the transmission of nervous impulses, and $\mathrm{Mg}$ is a cofactor in more than 300 enzymatic reactions. Trace elements ( $\mathrm{Fe}, \mathrm{Cu}, \mathrm{Co}, \mathrm{Zn}, \mathrm{Mn}, \mathrm{Mo})$ are also needed for the proper functioning of the organism but are required in smaller quantities [8-13]. These trace elements are involved in numerous biological processes: $\mathrm{Fe}$ is involved in oxygen transport, $\mathrm{Co}$ is an element forming part of cobalamin or vitamin $\mathrm{B} 12$, and $\mathrm{Mo}, \mathrm{Mn}, \mathrm{Zn}$, or $\mathrm{Cu}$ are components in many enzymes [14-16]. The Food and Agricultural Organization/World Health Organization (FAO/WHO) and the European Food Safety Authority (EFSA) have set recommended daily intake (RDI) values for the essential elements (Table 1).

In the case of Cape Verde, with the aim of strengthening the national nutritional surveillance and of improving the nutritional framework, the authorities developed the National Food and Nutrition Plan setting out guidelines and strategies to be implemented in the 2021-2025 period, contemplating food programs, aligned with the new challenges and in accordance with international recommendations [3]. The National Food and Nutrition Plan includes cereals and their derivatives as they are one of the most accessible foods for the population of Cape Verde, and, therefore, it is important to evaluate their nutritional value. As an example, Cape Verdean legislation states that wheat flour, which is commercialized and available to the final consumer, should be fortified with Fe. According to the WHO (World Health
Organization), flour fortification programs should include appropriate Quality Assurance and Quality Control (QA/ QC) programs at mills as well as regulatory and public health monitoring of the nutrient content and assessment of the nutritional/health impacts of the fortification strategies $[17,18]$. The concentration of iron in the final product depends on the nutrient extraction level and the type of compounds used in the fortification process (ethylenediaminetetraacetate-NaFeEDTA, ferrous sulfate, ferrous fumarate, ferrous) $[17,18]$.

Considering the importance of cereals and their derivatives in the diet, the aims of the present study are (i) to determine the content of essential elements ( $\mathrm{Na}, \mathrm{K}, \mathrm{Ca}, \mathrm{Mg}, \mathrm{Fe}$, $\mathrm{Cu}, \mathrm{Zn}, \mathrm{Mo}, \mathrm{Co}, \mathrm{Mn}$ ) in cereals and their derivatives, (ii) to study the possible significative differences or correlations between the essential elements in these cereals/derivatives, and (iii) to assess the dietary intake of the analyzed elements from the consumption of these cereals/derivatives by the population.

\section{Materials and Methods}

\section{Samples and Sample Treatment}

\section{Samples}

A total of 126 samples of cereals and derivatives were acquired from the following two regions of Cape Verde: Santiago and São Vicente. Table 2 shows the analyzed samples, the location where the samples were collected, and the origin of the cereal if available on the label. The analyzed cereals were corn, wheat, and rice (white), and the cereal derivatives were corn flour, wheat flour (plain), and corn gofio. The analyzed samples of corn gofio contained sea salt and traces of wheat, soy, egg, milk, sesame, and almonds

Table 1 Guideline dietary intake values of essential elements for adults

\begin{tabular}{|c|c|c|c|c|c|c|c|c|c|c|}
\hline Group & $\begin{array}{l}\mathrm{K} \\
\text { (mg/day) }\end{array}$ & $\begin{array}{l}\mathrm{Na} \\
(\mathrm{mg} / \text { day })\end{array}$ & $\begin{array}{l}\mathrm{Cu} \\
(\mathrm{mg} / \text { day })\end{array}$ & $\begin{array}{l}\text { Mo } \\
\text { (mg/day) }\end{array}$ & $\begin{array}{l}\text { Mn } \\
\text { (mg/day) }\end{array}$ & \multicolumn{5}{|c|}{ Reference } \\
\hline $\begin{array}{l}\text { Women } \\
(\geq 18)\end{array}$ & 3500 & 2000 & 1.3 & 0.065 & 3 & \multicolumn{5}{|l|}{ [13] } \\
\hline $\begin{array}{l}\text { Men } \\
(\geq 18)\end{array}$ & 3500 & 2000 & 1.6 & 0.065 & 3 & & & & & \\
\hline \multirow[t]{2}{*}{ Group } & \multirow{2}{*}{$\begin{array}{l}\mathrm{Ca} \\
\text { (mg/day) }\end{array}$} & \multirow{2}{*}{$\begin{array}{l}\mathrm{Mg} \\
\text { (mg/day) }\end{array}$} & \multicolumn{3}{|l|}{ Zn (mg/day) } & \multicolumn{4}{|c|}{$\mathrm{Fe}$ (mg/day) } & Reference \\
\hline & & & High bv & Moderate bv & Low bv & $15 \%$ bv & $12 \% \mathrm{bv}$ & $10 \%$ bv & $5 \%$ bv & {$[17]$} \\
\hline $\begin{array}{l}\text { Premenopausal women } \\
\text { (19-50 years of age) }\end{array}$ & 1000 & 220 & 3.0 & 4.9 & 9.8 & 19.6 & 24.5 & 29.4 & 58.8 & \\
\hline $\begin{array}{l}\text { Menopausal women } \\
\text { (51-65 years of age) }\end{array}$ & 1300 & 220 & 3.0 & 4.9 & 9.8 & 7.5 & 9.4 & 11.3 & 22.6 & \\
\hline $\begin{array}{l}\text { Men } \\
\text { (19-65 years of age) }\end{array}$ & 1000 & 260 & 4.2 & 7.0 & 14.0 & 9.1 & 11.4 & 13.7 & 27.4 & \\
\hline
\end{tabular}

$b v$., bioavailability 
Table 2 Analyzed cereal and derivatives samples according to origin and place of harvesting

\begin{tabular}{lllll}
\hline Type & $\begin{array}{l}\text { No. of } \\
\text { sam- } \\
\text { ples }\end{array}$ & Sampling location & Product and market & Origin $^{\text {a }}$ \\
\hline Rice (white) & 56 & Santiago & $\begin{array}{l}\text { Bulk product, local market } \\
\text { Packed, local market }\end{array}$ & $\begin{array}{l}\text { Brazil, Vietnam, Thailand, Japan, the USA (California), Pakistan } \\
\text { Unknown }\end{array}$ \\
Corn gofio & 6 & & Packed, local market & Portugal, the Netherlands \\
Corn flour & 10 & & Packed, local market & Portugal, France \\
Wheat flour (plain) & 17 & & Bulk product, local market & Argentina, France, Russia, South America \\
Corn & 13 & & Bulk product, local market & Russia, France \\
Wheat & 2 & Sulk product, local market & Brazil, Vietnam, Thailand, Japan, the USA (California), Pakistan \\
Rice (white) & 10 & Packed, local market & Unknown \\
Corn gofio & 2 & & Packed, local market & Portugal, the Netherlands \\
Corn flour & 2 & & Packed, local market & Portugal, France \\
Wheat flour (plain) & 4 & & Bulk product, local market & Argentina, France, Russia, South America \\
Corn & 4 & & Bulk product, local market & Russia, France, Spain \\
Wheat & 22 & & &
\end{tabular}

${ }^{a}$ Main importers of Cabo Verde: CORIN—Comercio Geral S.A., Minimercado Matilde—Productos Alimentares, MOAVE—Moagem de Cabo Verde S.A., IMPORTEX - Comercio e Representaçoes, CIC—Companhia de Investimentos de Cereais de Cabo Verde, Bento S.A., ITOMDistribuidora Limitada, Irmaos Correia LDA, Silos Marangatu—Segurança Alimentaria

${ }^{\mathrm{b}}$ Contains sea salt and traces of wheat, soy, egg, milk, sesame, and almonds

Table 3 Instrumental microwave conditions for wet digestion of samples

\begin{tabular}{llll}
\hline No & Ramp (min) & Temperature $\left({ }^{\circ} \mathrm{C}\right)$ & Time $(\min )$ \\
\hline 1 & $15^{\prime} 00^{\prime \prime}$ & 50 & $5^{\prime} 00^{\prime \prime}$ \\
2 & $5^{\prime} 00^{\prime \prime}$ & 60 & $4^{\prime} 00^{\prime \prime}$ \\
3 & $5^{\prime} 00^{\prime \prime}$ & 70 & $3^{\prime} 00^{\prime \prime}$ \\
4 & $3^{\prime} 00^{\prime \prime}$ & 90 & $2^{\prime} 00^{\prime \prime}$ \\
5 & $20^{\prime} 00^{\prime \prime}$ & 180 & $10^{\prime} 00^{\prime \prime}$ \\
\hline
\end{tabular}

Microwave processing power, $850 \mathrm{~W}$; limit temperature, $200{ }^{\circ} \mathrm{C}$; cooling temperature, $50{ }^{\circ} \mathrm{C}$

$[19,20]$. Gofio is a product made from whole cereal grains (mainly, corn), including the husk, which are roasted and ground until a dark colored flour is obtained, and it may also contain salt as an additive [21].

\section{Sample Treatment}

One gram of each sample was weighed using laboratory scale balance (ME4002, Mettler Toledo, USA) in a Teflon tube (HVT50, Anton Paar, Austria). Four milliliters of nitric acid $\left(\mathrm{HNO}_{3}\right)$ at $65 \%$ reagent quality (Sigma-Aldrich, Germany) and $2 \mathrm{~mL}$ of hydrogen peroxide $\left(\mathrm{H}_{2} \mathrm{O}_{2}\right)$ (SigmaAldrich, Germany) were then added. Samples were subjected to a wet microwave digestion process (Multiwave Go, Anton Paar, Austria) (Table 3) [22]. The digestion process lasted for $1 \mathrm{~h}$. Once the samples had been digested, they were placed in $10-\mathrm{mL}$ volumetric flasks, made up to the mark with Milli-Q quality distilled water, and transferred to hermetic containers for measurement (in triplicate). The proportion was 1:10 (w/v).

\section{Determination of the Content of Essential Elements}

Inductively coupled plasma-optical emission spectrometry (ICP-OES) using the ICAP 6300 model (Duo Thermo Scientific, Waltham, MA, USA) with an attached auto sampler (Auto Sampler, CETAX model ASX-520) was used to determine the essential element contents [23]. Instrumental conditions, wavelengths, and limits of quantification are shown in Table 4.

In determining the elements $\mathrm{Na}, \mathrm{Ca}, \mathrm{K}$, and $\mathrm{Mg}$, the certified standard IV-STOCK-2 (Inorganic Ventures Inc., Christiansburg, VA, USA) was used with a certified concentration of $0.01 \mathrm{mg} / \mathrm{mL}$ for each element indicated. The certified standard Multi-Element Std (SCP28AES, SCP Science, Quebec, Canada) with a certified concentration of $100 \mathrm{mg} / \mathrm{L}$ was used for the determination of $\mathrm{Mn}, \mathrm{Fe}, \mathrm{Cu}$, Zn, Mo, and Co.

The validation parameters that were verified in this analytical method were specificity, precision (established as reproducibility), and accuracy (stated as recovery). These parameters were verified with the measurement, under reproducibility conditions, of above-mentioned reference materials (ten times each). The results of the verification procedure were the following: Specificity, the method was found to be free of spectral interference for each of the metals studied; Precision, this was confirmed for each of the metals, with a HORRAT $\mathrm{R}_{\mathrm{R}}$ value $<2$; Accuracy, the recovery of the elements studied in the reference material was $>94 \%$ in all 
Table 4 ICP-OES instrumental conditions, instrumental wavelengths, limits of quantification, and quality control of the method

\begin{tabular}{|c|c|c|c|}
\hline \multicolumn{4}{|l|}{ ICP-OES instrumental conditions } \\
\hline RF power & $1150 \mathrm{~W}$ & $\begin{array}{l}\text { Injection of the sample } \\
\text { (flow pump) }\end{array}$ & $50 \mathrm{rpm}$ \\
\hline $\begin{array}{l}\text { Gas flow } \\
\text { (nebulizer \& auxiliary) }\end{array}$ & $0.5 \mathrm{~L} / \mathrm{min}$ & Stabilization time & $0 \mathrm{~s}$ \\
\hline Instrumental wavelengths (nm) & & $\mathrm{LOQ}^{\mathrm{a}}(\mathrm{mg} / \mathrm{kg})$ & \\
\hline $\mathrm{Ca}$ & 317.9 & 19.95 & \\
\hline Co & 228.6 & 0.06 & \\
\hline $\mathrm{Cu}$ & 327.3 & 0.12 & \\
\hline $\mathrm{Fe}$ & 259.9 & 0.09 & \\
\hline K & 769.9 & 18.84 & \\
\hline $\mathrm{Mg}$ & 279.1 & 19.43 & \\
\hline $\mathrm{Mn}$ & 257.6 & 0.08 & \\
\hline Mo & 202.0 & 0.02 & \\
\hline $\mathrm{Na}$ & 589.6 & 36.55 & \\
\hline $\mathrm{Zn}$ & 206.2 & 0.07 & \\
\hline \multicolumn{4}{|l|}{ Quality control method } \\
\hline & Found conc. $(\mathrm{mg} / \mathrm{kg})$ & Certified conc. $(\mathrm{mg} / \mathrm{kg})$ & Recovery (\%) \\
\hline $\mathrm{Ca}^{\mathrm{b}}$ & $1967 \pm 113$ & $1961.1 \pm 158$ & 99.7 \\
\hline $\mathrm{Co}^{\mathrm{c}}$ & $0.09 \pm 0.00$ & $0.09 \pm 0.00$ & 100 \\
\hline $\mathrm{Cu}^{\mathrm{d}}$ & $2.1 \pm 0.2$ & $2.09 \pm 0.4$ & 99.7 \\
\hline $\mathrm{Fe}^{\mathrm{d}}$ & $14.1 \pm 0.5$ & $13.9 \pm 0.3$ & 98.9 \\
\hline $\mathrm{K}^{\mathrm{b}}$ & $6970 \pm 125$ & $6858.5 \pm 318$ & 98.4 \\
\hline $\mathrm{Mg}^{\mathrm{b}}$ & $580 \pm 26.7$ & $575 \pm 25.7$ & 98.1 \\
\hline $\mathrm{Mn}^{\mathrm{d}}$ & $9.4 \pm 0.9$ & $9.3 \pm 0.5$ & 98.9 \\
\hline $\mathrm{Mo}^{\mathrm{c}}$ & $0.09 \pm 0.01$ & $0.09 \pm 0.02$ & 99.4 \\
\hline $\mathrm{Na}^{\mathrm{b}}$ & $8132 \pm 942$ & $8001.9 \pm 476$ & 98.4 \\
\hline $\mathrm{Zn}^{\mathrm{d}}$ & $11.6 \pm 0.4$ & $11.4 \pm 0.2$ & 98.2 \\
\hline
\end{tabular}

${ }^{a}$ LOQ (limits of quantification), calculated as 10 times the standard deviation (SD) resulting from the analysis of 15 targets under reproducibility conditions

${ }^{\mathrm{b}} \mathrm{SRM}$ 1548a typical diet

${ }^{\mathrm{c}} \mathrm{SRM} 1515$ apple leaves

${ }^{\mathrm{d}}$ SRM 1567 a wheat flour cases (Table 4), with no significant differences $(p<0.05)$. Therefore, the method used met the criteria of accuracy (established as recovery), precision (established as reproducibility), and specificity as established in the EC REGULATION No. 333/2007 [24] (Table 4).

\section{Statistical Analysis}

GraphPad Prism 8.4.3 software for Windows ${ }^{\mathrm{TM}}$ was used for the statistical analysis, and the Anderson-Darling, D'Agostino and Pearson, Shapiro-Wilk, and Kolmogorov-Smirnov tests were applied $[25,26]$. As data did not follow a normal distribution, the Mann-Whitney test was applied [27]. Values of $p<0.05$ were considered statistically significant. The existence of possible significant differences between cereals and their derivatives (rice, corn gofio, corn flour, wheat flour, corn, and wheat) and between origins (Santiago and São Vicente) was studied, and a correlation study based on the Spearman correlation coefficient [28] was conducted to find possible positive and/or negative correlations between the different elements analyzed.

\section{Dietary Intake Assessment Calculations}

The estimated daily intake (EDI) of the different essential and trace elements derived from the consumption of cereals and derivatives was calculated. The EDI is defined as the estimated amount of a substance and/or chemical element, in this case, an essential/trace element, which is ingested daily from a portion of food, in this case, the cereals and derivatives [29].

$\mathrm{EDI}=$ Cereal consumption $\times$ Element concentration

The different guideline values set for each one of the analyzed elements were used to evaluate the EDI (see 
Table 1). A contribution percentage to these guideline values was estimated for the daily consumption of each cereal/derivative and each essential element. Even though corn consumption in Cape Verde was 30,157 tons (almost $150 \mathrm{~g}$ /day per citizen), rice consumption 25,996 tons (almost $120 \mathrm{~g} /$ day per citizen), wheat 16,907 tons (around $80 \mathrm{~g} /$ day per citizen), and wheat flour 11,760 tons (around $60 \mathrm{~g} /$ day per citizen), a $100 \mathrm{~g} /$ day portion of every cereal or cereal derivative was considered as the daily consumption [6].

Contribution $(\%)=\frac{E D I}{\text { Reference intake value }} \times 100$

\section{Results and Discussion}

\section{Content of Essential Elements in Cereals and Derivatives}

Wheat samples had the highest mean average level of $\mathrm{Mg}(806 \pm 358 \mathrm{mg} / \mathrm{kg} \mathrm{ww})$, and the contents of $\mathrm{Mn}$ $(18.5 \pm 13.6 \mathrm{mg} / \mathrm{kg} \mathrm{ww})$ and $\mathrm{Zn}(15.3 \pm 4.70 \mathrm{mg} / \mathrm{kg} \mathrm{ww})$ in wheat samples are also noteworthy (Table 5). This fact is important because a deficient intake of $\mathrm{Mg}$ is related to cardiovascular diseases, type 2 diabetes, etc. [30]. Studies carried out by Laskowski et al. [31] showed that cereals are the main source of $\mathrm{Mg}$ in the diet. Wheat flour had the highest mean average concentration of $\mathrm{Na}(294 \pm 1254 \mathrm{mg} / \mathrm{kg}$ ww) and $\mathrm{Ca}(191 \pm 68.6 \mathrm{mg} / \mathrm{kg} \mathrm{ww})$, but wheat flour was found to have a lower $\mathrm{Mg}$ concentration $(416 \pm 274 \mathrm{mg} / \mathrm{kg}$ ww). These data suggest that the processing of cereals can decrease their nutritional quality [30].

Corn gofio had the highest mean average content of $\mathrm{K}$ $(2503 \pm 697 \mathrm{mg} / \mathrm{kg} \mathrm{ww})$. As mentioned above, the concentrations of certain elements may be higher in "gofio" because this derivative is made with wholegrain cereal including the husk [32, 33].

Figure 1 shows the comparison in the content of the elements for each sample group analyzed. Due to the disparity between the samples analyzed, the standard deviations (SD) are sometimes higher than the mean concentrations. Not only did the commercialized samples in Cape Verde have different origins (sometimes unknown) but some samples contained added fortified ingredients.

TatahMentan et al. [34] determined essential elements in white rice from the USA, Thailand, India, and Italy and found lower levels of $\mathrm{Mg}(260 \mathrm{mg} / \mathrm{kg}), \mathrm{Ca}(57 \mathrm{mg} / \mathrm{kg}), \mathrm{K}$ $(833 \mathrm{mg} / \mathrm{kg})$, and $\mathrm{Fe}(4.3 \mathrm{mg} / \mathrm{kg})$ than the results of the present study, whereas the mean average concentration of

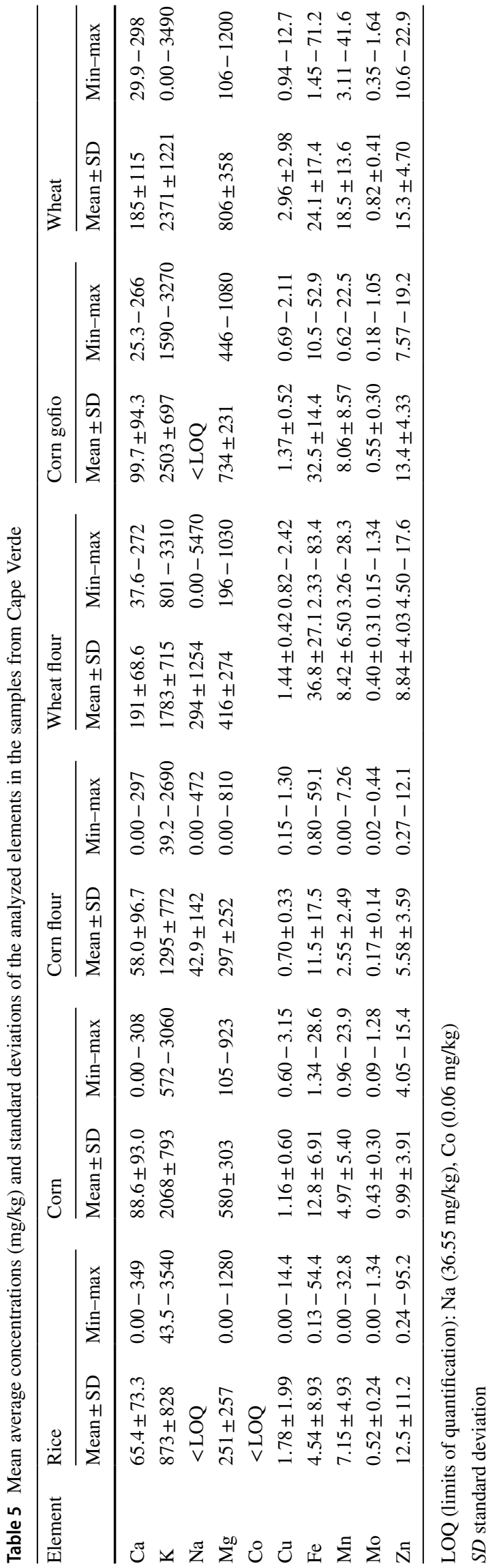



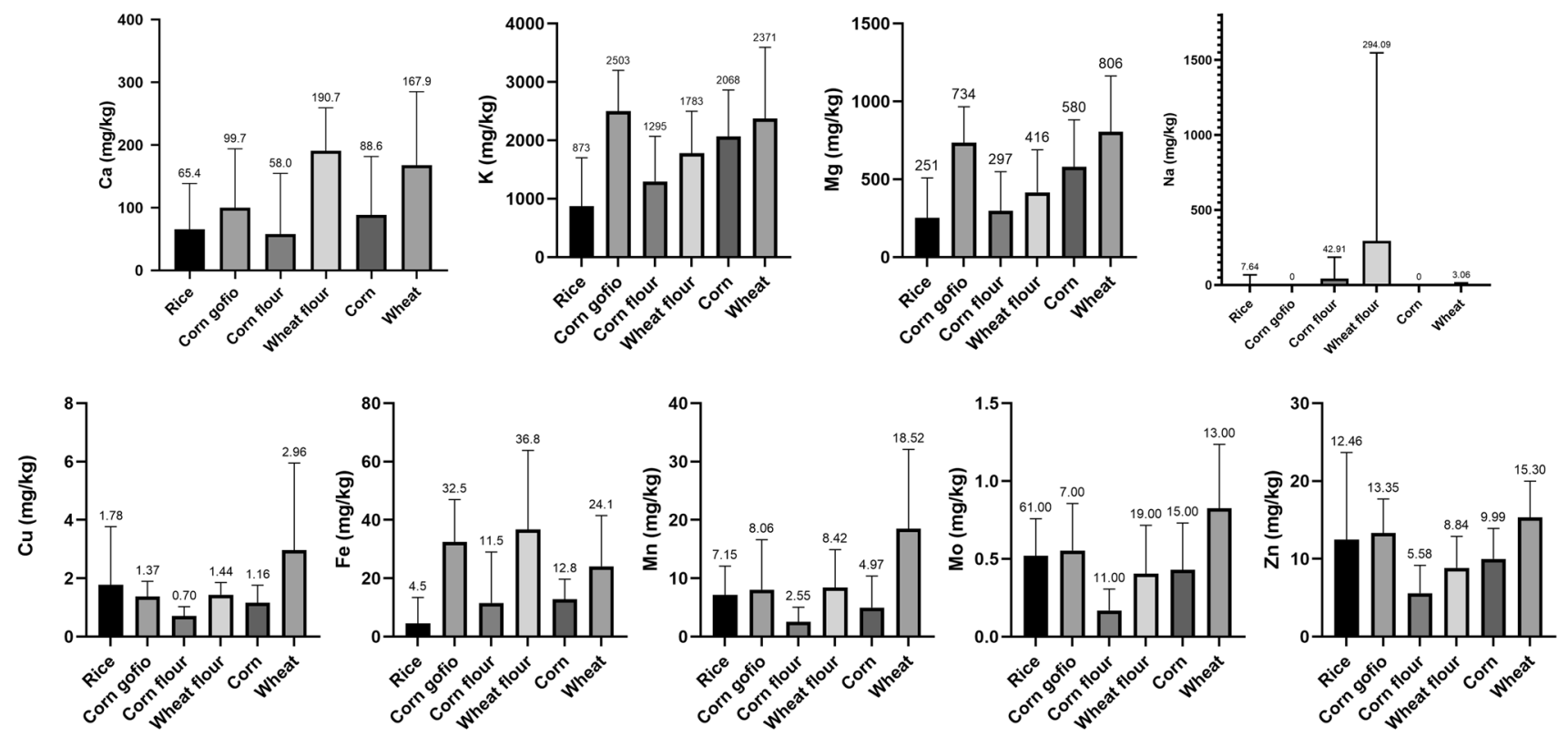

Fig. 1 Box graph of the statistical analysis by cereal type

Mn $(11 \mathrm{mg} / \mathrm{kg})$ was higher in white rice from the USA and Thailand, India, and Italy. Zn concentrations in white rice $(12.5 \mathrm{mg} / \mathrm{kg})$ from the research did not have significant differences with the commercial rice in Cape Verde $(12.5 \mathrm{mg} /$ $\mathrm{kg})$.

Other authors have also reported that the concentrations of the analyzed elements in the cereals and derivatives commercialized in Cape Verde differ from both the EFSA food composition database and the INSA (Institute for Research on Nutrition and Food Safety) food composition table $[35,36]$.

An example of the above is the case of $\mathrm{Ca}$; $\mathrm{Ca}$ concentrations in the different types of cereals analyzed in Cape Verde in the present study were lower than the mean average $\mathrm{Ca}$ values reported both by EFSA (wheat flour, $351.7 \mathrm{mg} / \mathrm{kg}$; common wheat grain, $285 \mathrm{mg} / \mathrm{kg}$; polished rice, $102 \mathrm{mg} /$ $\mathrm{kg}$; corn flour, $113.3 \mathrm{mg} / \mathrm{kg}$ ) and INSA (wheat flour, $280 \mathrm{mg} / \mathrm{kg}$; raw dry corn, $140 \mathrm{mg} / \mathrm{kg}$; corn flour, $80 \mathrm{mg} /$ $\mathrm{kg}$ ) (Table 6). Furthermore, the K content was lower in the analyzed samples than the mean average $K$ concentration reported in the INSA and EFSA databases (common wheat grain, $3171.4 \mathrm{mg} / \mathrm{kg}$; polished rice, $1187 \mathrm{mg} / \mathrm{kg}$; corn flour, $1667 \mathrm{mg} / \mathrm{kg}$; corn grain, $2900 \mathrm{mg} / \mathrm{kg}$ ) [35, 36]. In the case of $\mathrm{Mg}$, the recorded concentrations were higher in the samples of wheat and corn flour commercialized in Cape Verde than the values reported by EFSA (wheat flour, $183.3 \mathrm{mg} / \mathrm{kg}$ ) and INSA (corn grain, $80 \mathrm{mg} / \mathrm{kg}$ ) [35, 36].

The differences in levels confirm that the origin of the crop/cereal and the derivatives' manufacturing process may impact the metal content of final products. This is the reason why the authors of the present work believe that any dietary exposure assessment should be carried out considering updated data obtained from each population under study.

Significant differences $(p<0.05)$ were found between all types of cereals and derivatives (rice, wheat, corn, corn gofio, wheat flour, corn flour) for almost all the elements determined, except for $\mathrm{Na}$ and $\mathrm{Co}$. These differences may be associated with various factors. Not only do the intrinsic characteristics of the plant and the soil in which the cereal is grown ( $\mathrm{pH}$, organic matter, carbonate, and oxide content, etc.) directly influence the content of elements, but there are also other important factors such as the climatic conditions of the region where these crops are grown [37]. A recent study carried out by Soares et al. [38] reported a noteworthy interaction between individual climatic factors and the content of nitrogen $(\mathrm{N})$, potassium $(\mathrm{K})$, iron $(\mathrm{Fe})$, and phosphorus $(\mathrm{P})$ in cultivation soils.

The results of the present research should be viewed considering some limitations. Not knowing the origin of some of the analyzed samples may have a significant influence in the final element content of the cereal and derivatives, and therefore, this is considered a limitation in the results and discussion of this study. The importance of informative labeling that indicates the country and area of origin of the cereal is again pointed out as an essential component of an exposure assessment. Therefore, the authors suggest that every product sold to the public should provide information regarding its cultivation area (origin) on the label. Some of the secondary ingredients may enrich the final product in 
Table 6 Statistical differences between the analyzed samples and $p$ value

\begin{tabular}{|c|c|c|c|c|c|c|}
\hline Element & Rice & Corn & Corn flour & Wheat flour & Corn gofio & Wheat \\
\hline $\mathrm{Ca}$ & $\begin{array}{l}\text { vs corn flour } \\
\quad(0.0027) \\
\text { vs wheat }(0.011)\end{array}$ & $\begin{array}{l}\text { vs corn flour } \\
\quad(0.0408) \\
\text { vs wheat flour } \\
\quad(0.0015)\end{array}$ & $\begin{array}{l}\text { vs wheat flour } \\
(0.0008)\end{array}$ & vs rice $(<0.0001)$ & $\begin{array}{l}\text { vs corn flour } \\
(0.0317)\end{array}$ & vs corn flour $(0.003)$ \\
\hline $\mathrm{K}$ & $\begin{array}{l}\text { vs corn flour }(0.015) \\
\text { vs wheat flour } \\
\quad(<0.0001)\end{array}$ & $\begin{array}{l}\text { vs corn flour } \\
\quad(0.0246) \\
\text { vs rice }(<0.0001)\end{array}$ & $\begin{array}{l}\text { vs corn gofio } \\
\qquad(0.0041) \\
\text { vs wheat }(0.0246)\end{array}$ & $\begin{array}{l}\text { vs corn flour } \\
(0.0452)\end{array}$ & $\begin{array}{l}\text { vs wheat flour } \\
\qquad(0.0223) \\
\text { vs rice }(<0.0001)\end{array}$ & vs rice $(0.0056)$ \\
\hline $\mathrm{Na}$ & Non detected & Non detected & Non detected & Non detected & Non detected & Non detected \\
\hline $\mathrm{Mg}$ & $\begin{array}{l}\text { vs corn gofio } \\
\qquad(<0.0001) \\
\text { vs wheat }(<0.0001)\end{array}$ & $\begin{array}{l}\text { vs corn flour } \\
\quad(0.0204) \\
\text { vs rice }(0.0001)\end{array}$ & $\begin{array}{l}\text { vs corn gofio } \\
\quad(0.0044) \\
\text { vs wheat flour } \\
\quad(0.0161)\end{array}$ & vs rice $(0.0003)$ & $\begin{array}{l}\text { vs wheat flour } \\
(0.0056)\end{array}$ & $\begin{array}{l}\text { vs corn flour }(0.0069) \\
\text { vs wheat flour } \\
\quad(0.0096)\end{array}$ \\
\hline $\mathrm{Co}$ & Non detected & Non detected & Non detected & Non detected & Non detected & Non detected \\
\hline $\mathrm{Cu}$ & $\begin{array}{l}\text { vs corn flour } \\
(<0.0001)\end{array}$ & Non detected & vs rice $(<0.0001)$ & Non detected & Non detected & vs rice $(0.0003)$ \\
\hline $\mathrm{Fe}$ & $\begin{array}{l}\text { vs corn flour } \\
\quad(0.0036) \\
\text { vs wheat flour } \\
\quad(<0.0001)\end{array}$ & $\begin{array}{l}\text { vs wheat }(0.0176) \\
\text { vs rice }(<0.0001)\end{array}$ & $\begin{array}{l}\text { vs corn gofio } \\
\quad(0.0083) \\
\text { vs wheat flour } \\
\quad(0.0017)\end{array}$ & vs corn $(0.0124)$ & $\begin{array}{l}\text { vs corn }(0.0029) \\
\text { vs rice }(<0.0001)\end{array}$ & vs rice $(<0.0001)$ \\
\hline Mn & vs wheat $(0.0126)$ & $\begin{array}{l}\text { vs rice }(0.0001) \\
\text { vs wheat }(0.0008)\end{array}$ & vs rice $(<0.0001)$ & $\begin{array}{l}\text { vs corn flour } \\
\quad(0.0002) \\
\text { vs corn }(0.0004)\end{array}$ & vs wheat $(0.0456)$ & vs corn flour (0.0002) \\
\hline Mo & $\begin{array}{l}\text { vs corn flour } \\
\quad(<0.0001) \\
\text { vs wheat flour } \\
\quad(0.0136)\end{array}$ & $\begin{array}{l}\text { vs corn flour } \\
(0.0015)\end{array}$ & $\begin{array}{l}\text { vs wheat flour } \\
(0.0005)\end{array}$ & vs wheat $(0.0008)$ & vs corn flour (0.002) & $\begin{array}{l}\text { vs rice }(0.0085) \\
\text { vs corn flour } \\
\quad(<0.0001)\end{array}$ \\
\hline $\mathrm{Zn}$ & $\begin{array}{l}\text { vs corn flour } \\
(<0.0001)\end{array}$ & $\begin{array}{l}\text { vs corn flour } \\
\qquad(0.0056) \\
\text { vs wheat }(0.0201)\end{array}$ & $\begin{array}{l}\text { vs corn gofio } \\
\qquad(0.0028) \\
\text { vs wheat }(<0.0001)\end{array}$ & $\begin{array}{l}\text { vs rice }(0.0056) \\
\text { vs corn flour } \\
(0.0120)\end{array}$ & $\begin{array}{l}\text { vs wheat flour } \\
(0.0121)\end{array}$ & $\begin{array}{l}\text { vs wheat }(0.0016) \\
\text { vs wheat flour }(0.001)\end{array}$ \\
\hline
\end{tabular}

terms of the analyzed elements here, and as such the final concentration observed may not be completely attributable to the main cereal ingredient. Nevertheless, this limitation does not affect the exposure assessment estimation because the portion of the final product consumed by the Cape Verde population is what matters here.

\section{Study of Correlations Between Elements}

Figure 2 shows the results of the Spearman $r$ correlation study. Positive correlations were found between $\mathrm{Mn}-\mathrm{Ca}$, $\mathrm{Fe}-\mathrm{Ca}, \mathrm{Mn}-\mathrm{Cu}$, Mo-Cu, Mo- $\mathrm{Cu}, \mathrm{Zn}-\mathrm{Cu}, \mathrm{Cu}-\mathrm{Ca}, \mathrm{K}-\mathrm{Fe}$, $\mathrm{Mg}-\mathrm{Fe}, \mathrm{Ca}-\mathrm{Fe}, \mathrm{K}-\mathrm{Mg}$, Mn-Mo, and Mo-Zn. Positive correlations indicate the absence of competitiveness between elements and the simultaneous presence of elements without interference. The literature on the correlations between essential and trace elements in cereals is scarce. Studies conducted by Simic et al. [39] determined positive correlations between $\mathrm{Cu}-\mathrm{Fe}$ and $\mathrm{Fe}-\mathrm{Mo}$ in corn. Although the physiological mechanisms between elements are not clearly known, the above authors suggest that the positive correlations found imply the possibility of simultaneously improving the element content in the corn grain [39]. Negative correlations were found between Mo-Na and

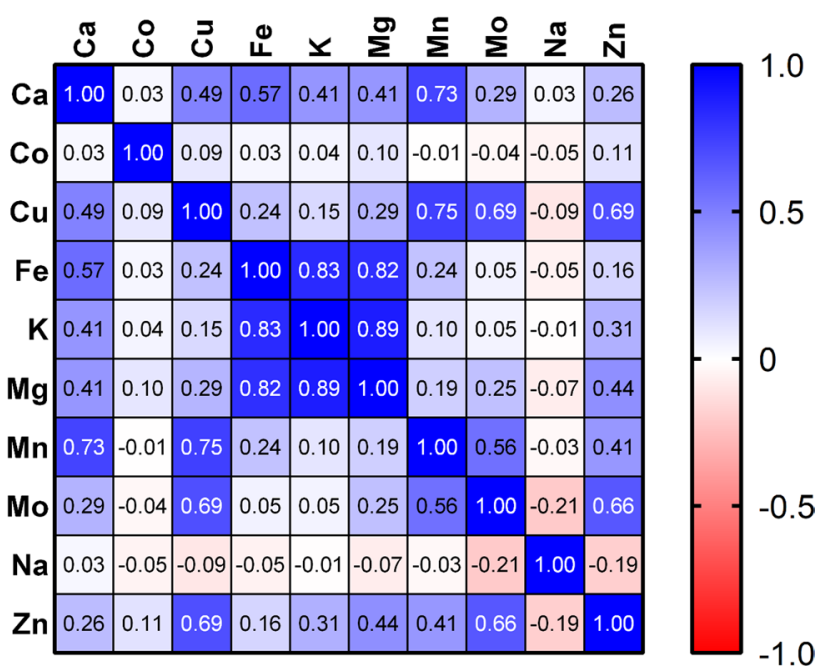

Fig. 2 Correlations Spearman coefficient results 
Table 7 Estimated daily intake (EDI) of the essential elements according to cereal type and derivatives for a consumption of $100 \mathrm{~g} /$ day

\begin{tabular}{lclllll}
\hline Element & \multicolumn{2}{l}{ EDI (mg/day) } & & \\
\cline { 2 - 7 } & Rice & Corn & Corn flour & Wheat flour & Corn gofio & Wheat \\
\hline $\mathrm{Ca}$ & 6.54 & 8.86 & 5.80 & 19.1 & 9.97 & 18.5 \\
$\mathrm{~K}$ & 87.3 & 207 & 130 & 178 & 250 & 237 \\
$\mathrm{Na}$ & - & - & 4.29 & 29.4 & - & - \\
$\mathrm{Mg}$ & 25.1 & 58.0 & 29.7 & 41.6 & 73.4 & 80.6 \\
$\mathrm{Fe}$ & 0.45 & 1.28 & 1.15 & 3.68 & 3.25 & 2.41 \\
$\mathrm{Cu}$ & 0.18 & 0.12 & 0.07 & 0.14 & 0.14 & 0.30 \\
$\mathrm{Co}$ & - & - & - & - & - & - \\
$\mathrm{Mo}$ & 0.05 & 0.04 & 0.02 & 0.04 & 0.06 & 0.08 \\
$\mathrm{Mn}$ & 0.72 & 0.50 & 0.26 & 0.84 & 0.81 & 1.85 \\
$\mathrm{Zn}$ & 1.25 & 0.99 & 0.56 & 0.88 & 1.34 & 1.53 \\
\hline
\end{tabular}

$\mathrm{Na}-\mathrm{Zn}$ and suggest interference between these elements. These data should be considered with caution because, in some of the cereal products analyzed, the manufacturer has added salt, which interferes with the study of correlations. Without any doubt, it is necessary to carry out
Table 8 Contribution percentages to the guideline values for men (19-50 years of age), women (premenopausal, 19-50 years of age), and women (postmenopausal (19-65 years of age) set by the FAO [17]

\begin{tabular}{llrrrrrr}
\hline Element & Group & \multicolumn{7}{l}{ \%Contribution to the guideline values } \\
\cline { 3 - 7 } & & Rice & Corn & Corn flour & Wheat flour & Corn gofio & Wheat \\
\hline $\mathrm{Ca}$ & Men & 0.65 & 0.89 & 0.58 & 1.91 & 1.00 & 1.85 \\
& Women (premenopausal) & 0.65 & 0.89 & 0.58 & 1.91 & 1.00 & 1.85 \\
& Women (postmenopausal) & 0.50 & 0.68 & 0.45 & 1.47 & 0.77 & 1.42 \\
$\mathrm{Mg}$ & Men & 9.65 & 22.3 & 11.4 & 9.65 & 16.0 & 36.6 \\
& Women (pre- and postmenopausal) & 11.4 & 26.4 & 13.5 & 11.4 & 18.9 & 31.0 \\
$\mathrm{Zn}^{\mathrm{a}}$ & Men & 29.8 & 23.6 & 13.3 & 21.0 & 31.9 & 36.4 \\
& Women (pre- and postmenopausal) & 41.7 & 33.0 & 18.7 & 29.3 & 44.7 & 51.0 \\
$\mathrm{Zn}^{\mathrm{b}}$ & Men & 17.9 & 14.1 & 8.0 & 12.6 & 19.1 & 21.9 \\
& Women (pre- and postmenopausal) & 25.5 & 20.2 & 11.4 & 18.0 & 27.3 & 31.2 \\
$\mathrm{Zn}^{\mathrm{c}}$ & Men & 8.9 & 7.1 & 4.0 & 6.3 & 9.6 & 10.9 \\
& Women (pre- and postmenopausal) & 12.8 & 10.1 & 5.7 & 9.0 & 13.7 & 15.6 \\
$\mathrm{Fe}^{\mathrm{d}}$ & Men & 4.95 & 14.1 & 12.6 & 40.4 & 35.7 & 26.5 \\
& Women (premenopausal) & 2.30 & 6.5 & 5.9 & 18.8 & 16.6 & 12.3 \\
& Women (postmenopausal) & 6.00 & 17.1 & 15.3 & 49.1 & 43.3 & 32.1 \\
$\mathrm{Fe}^{\mathrm{e}}$ & Men & 3.95 & 11.2 & 10.1 & 32.3 & 28.5 & 21.1 \\
& Women (premenopausal) & 1.84 & 5.2 & 4.7 & 15.0 & 13.3 & 9.8 \\
& Women (postmenopausal) & 4.79 & 13.6 & 12.2 & 39.1 & 34.6 & 25.6 \\
$\mathrm{Fe}^{\mathrm{f}}$ & Men & 3.28 & 9.3 & 8.4 & 26.9 & 23.7 & 17.6 \\
& Women (premenopausal) & 1.53 & 4.4 & 3.9 & 12.5 & 11.1 & 8.2 \\
& Women (postmenopausal) & 3.98 & 11.3 & 10.2 & 32.6 & 28.8 & 17.6 \\
$\mathrm{Fe}^{\mathrm{g}}$ & Men & 1.64 & 4.7 & 4.2 & 13.4 & 11.9 & 8.8 \\
& Women (premenopausal) & 0.77 & 2.2 & 2.0 & 6.3 & 5.5 & 4.1 \\
& Women (postmenopausal) & 1.99 & 5.7 & 5.1 & 16.3 & 14.4 & 10.7 \\
\hline & & & & & & &
\end{tabular}

${ }^{a}$ High bioavailability

${ }^{\mathrm{b}}$ Moderate bioavailability

${ }^{\mathrm{c}}$ Low bioavailability

${ }^{\mathrm{d}} 15 \%$ bioavailability

e $12 \%$ bioavailability

${ }^{\mathrm{f}} 10 \%$ bioavailability

${ }_{5} 5 \%$ bioavailability 
Table 9 Contribution percentages to the guideline values for men $(\geq 18)$ and women $(\geq 18)$ set by EFSA [13]

\begin{tabular}{llcccccc}
\hline Element & Group & \multicolumn{7}{c}{ \%Contribution to the guideline values } \\
\cline { 3 - 8 } & & Rice & Corn & Corn flour & Wheat flour & Corn gofio & Wheat \\
\hline $\mathrm{K}$ & Men & 2.57 & 6.09 & 3.82 & 5.24 & 7.35 & 6.97 \\
& Women & 3.36 & 7.96 & 5.00 & 6.85 & 9.62 & 9.12 \\
$\mathrm{Na}$ & Men and women & - & - & 0.21 & 1.47 & - & - \\
$\mathrm{Cu}$ & Men & 11.3 & 7.5 & 4.4 & 8.8 & 8.8 & 18.8 \\
& Women & 13.8 & 9.2 & 5.4 & 10.8 & 10.8 & 23.1 \\
$\mathrm{Mo}$ & Men and women & 76.9 & 61.5 & 30.8 & 61.5 & 92.3 & 123 \\
$\mathrm{Mn}$ & Men and women & 24.0 & 16.7 & 8.7 & 28.0 & 27.0 & 61.7 \\
\hline
\end{tabular}

more studies on correlations between essential and trace elements in cereals and their derivatives.

\section{Dietary Intake Evaluation}

Tables 7, 8, and 9 show the estimated daily intake (EDI) of the analyzed elements assuming a consumption of $100 \mathrm{~g} /$ day of the analyzed cereals or derivatives. The evaluation of the dietary intakes was performed considering the "dietary reference values (DRV)" set by FAO [17] and EFSA [13].

The consumption of $100 \mathrm{~g} /$ day of wheat means a contribution of $123 \%$ of the DRV of Mo set at $65 \mu \mathrm{g} /$ day for adults [13]. Similarly, $100 \mathrm{~g} /$ day of wheat provides a noteworthy percentage $(61.7 \%)$ of the DRV of Mn set at $3 \mathrm{mg} /$ day for adults [13].

Iron deficiency in the Cape Verdean population is still considered a public health problem [40], and $20.6 \%$ of women of reproductive age (15 to 49 years old) have been diagnosed with anemia. The prevalence of anemia in nonpregnant women and pregnant women is $21 \%$ and $22.5 \%$, respectively. According to the results of the present study, $100 \mathrm{~g} /$ day of wheat flour provides (bearing in mind the $15 \%$ bioavailability rate for this element [17]) a contribution percentage to the recommended $\mathrm{Fe}$ intake of $40.4 \%$ for men, $18.8 \%$ for premenopausal women, and $46.1 \%$ for menopausal women. However, it should be noted the non-heme form of the Fe found in cereals hinders its absorption [41]. Therefore, a lower percentage of bioavailability should be considered $(5-10 \%)$, which means that the contribution percentages from the consumption of wheat flour (100 g/day) would be around $13.4-26.9 \%$ for men, $6.3-12.5 \%$ for premenopausal women, and $16.3-32.6 \%$ for menopausal women. These contribution percentages are equally noteworthy.

Considering that the Cape Verde National Food and Nutrition Plan (2021-2025) aims to reduce Fe anemia by encouraging the consumption of bio-fortified foods and by introducing means to ensure that the private sector fully complies with all the legislation regarding fortifying the iron and folic acid content of wheat flour [3], the consumption of cereals and cereal derivatives could help reduce the prevalence of anemia.
The $\mathrm{Mg}$ contribution from the consumption of $100 \mathrm{~g}$ per day of corn is also noteworthy, since this provides $36.6 \%$ (men) and $31.0 \%$ (pre- and postmenopausal women) of the Mg DRV set by the FAO (260 mg/day for men and $220 \mathrm{mg} /$ day for pre- and post-menopausal women) [17]. It should be noted that unprocessed cereals or derivatives such as gofio are the most recommended products for consumption to meet the daily $\mathrm{Mg}$ requirement.

\section{Conclusions}

This research work demonstrates the importance of the consumption of cereals and derivatives in the daily intake of essential elements. While wheat has high levels of $\mathrm{Mg}, \mathrm{Mn}$, and $\mathrm{Zn}$, wheat flour is a relevant source of $\mathrm{Na}, \mathrm{Ca}$, and $\mathrm{Fe}$ for the Cape Verde population. Corn gofio is noteworthy for its high $\mathrm{K}$ content. The differences observed in the analyzed samples show the importance of consuming a variety of cereals as opposed to the consumption of a single cereal/ derivative. The correlation study reveals negative correlations between Mo-Na and Na-Zn. This finding could suggest interference between these elements. The consumption of $100 \mathrm{~g} /$ day of wheat provides a notable contribution of $\mathrm{Mo}, \mathrm{Mn}, \mathrm{Fe}$, and $\mathrm{Mg}$. In addition, the fortification of cereal derivatives can counteract the decrease in the content of some essential elements in the final product. Considering the interest of the Cape Verdean public health authorities in the optimal nutritional status of its population, it is advisable to strengthen the promotion of the consumption of cereals and derivatives, especially in young populations.

Author Contribution Conceptualization: Carmen Rubio-Armendáriz and Arturo Hardisson. Data curation: Soraya Paz. Formal analysis: Consuelo Revert. Funding acquisition: Carmen Rubio-Armendáriz. Investigation: Ángel J. Gutiérrez, Consuelo Revert, and Soraya Paz. Methodology: Ángel J. Gutiérrez, Dailos González-Weller, and Soraya Paz. Project administration: Carmen Rubio-Armendáriz. Resources: Ángel J. Gutiérrez, Verena Gomes Furtado, Dailos González-Weller, and Arturo Hardisson. Supervision: Arturo Hardisson. Validation: 
Dailos González-Weller. Visualization: Verena Gomes Furtado, Consuelo Revert, and Arturo Hardisson. Writing — original draft: Soraya Paz. Writing — review and editing: Carmen Rubio-Armendáriz, Verena Gomes Furtado, and Soraya Paz.

Funding Open Access funding provided thanks to the CRUE-CSIC agreement with Springer Nature. This research was funded by PERVEMAC II: Programa de Cooperación INTERREG V-A EspañaPortugal MAC (Madeira-Azores-Canarias) 2014-2020 grant number MAC/1.1a/049. Project "Sustainable Agriculture and Food Security in Macaronesia: Investigation of the benefits and risks of the intake of plant products for the health of consumers and development of minimization strategies".

Data Availability The data supporting the findings of the study are available in the present manuscript.

\section{Declarations}

Conflict of Interest The authors declare no competing interests.

Open Access This article is licensed under a Creative Commons Attribution 4.0 International License, which permits use, sharing, adaptation, distribution and reproduction in any medium or format, as long as you give appropriate credit to the original author(s) and the source, provide a link to the Creative Commons licence, and indicate if changes were made. The images or other third party material in this article are included in the article's Creative Commons licence, unless indicated otherwise in a credit line to the material. If material is not included in the article's Creative Commons licence and your intended use is not permitted by statutory regulation or exceeds the permitted use, you will need to obtain permission directly from the copyright holder. To view a copy of this licence, visit http://creativecommons.org/licenses/by/4.0/.

\section{References}

1. FAO (Food and Agricultural Organization) (2021) FAO Cereal Supply and Demand Brief. Record cereal production seen keeping markets adequately supplied in 2021/22. Available online: https:// www.fao.org/worldfoodsituation/csdb/en/ Accessed 19 January 2022

2. MAA (Ministério de Agricultura e Ambiente) (2018) Inquérito Nacional sobre a Vulnerabilidade Alimentar e Nutricional das Famílias. Resultados Preliminares. [National Inquiry on the Food and Nutritional Vulnerability of Families. Preliminary results]. Cape Verde.

3. MSSS (Ministério da Saúde e Segurança Social) (2021) Plano Nacional de Alimentação e Nutrição, PNAN 2021-2025. [National Food and Nutrition Plan]. Cape Verde.

4. Dop MC, Pereira C, Mistura L, Martinez C, Cardoso E (2012) Using Household Consumption and Expenditures Survey (HCES) data to assess dietary intake in relation to the nutrition transition: a case study from Cape Verde. Food Nutr Bull 33(3_suppl2):S221S227. https://doi.org/10.1177/15648265120333S211

5. MAA (Ministério da Agricultura e Ambiente), INE (Instituto Nacional de Estatísticas) (2015) Estado nutricional da população cabo-verdiana. Medidas antropométricas. IDRF 2015. [Nutritional status of the Cape Verdean population. Anthropometric measures]. Cape Verde
6. SIMPA (Sistema de Informação do Mercado dos Produtos Alimentares). Available online: https://www.gpp.pt/index.php/sima/ sima-2018 Accessed 5 April 2021

7. Cabral D, Cunha LM, Vaz de Almeida MD (2019) Food choice and food consumption frequency of Cape Verde inhabitants. Appetite 139:26-34. https://doi.org/10.1016/j.appet.2019.04.005

8. Blanco A (2006) Química Biológica. [Biological chemistry]. 8th edition; Editorial El Ateneo, Madrid, Spain

9. Hurley SW, Johnson AK (2015) The biopsychology of salt hunger and sodium deficiency. Eur J Phy 467(3):445-456. https://doi.org/ 10.1007/s00424-014-1676-y

10. LPI (Linus Pauling Institute). Centro de Información de Micronutrientes. Minerales. Magnesio. [Micronutrient Information Center. Minerals. Magnesium]. Available online: http://lpi.oregonstate. edu/es/mic/minerales/magnesio Accessed 5 April 2021

11. Moll R, Davis B (2017) Iron, vitamin B12 and folate. Medicine 45(4):198-203. https://doi.org/10.1016/j.mpmed.2017.01.007

12. Weaver CM, Heaney RP (2006) Calcium in human health. Nutrition \& health; Humana Press, Nueva Jersey

13. EFSA (European Food Safety Authority). Dietary references values for EU. Adults. Both Genders. All ages. Available online: https://multimedia.efsa.europa.eu/drvs/index.htm Accessed 7 May 2021.

14. Fotedar A, Bhasin JS, Chakravarty A, Kulkarni A, Bhalla G, Anwar F, Rao S (2018) Effectiveness of iron-fortified infant cereals on hemoglobin levels of children aged 12-24 months: a cross-sectional study from New Delhi. India J Fam Med Prim Care 7(1):77-80. https://doi.org/10.4103/jfmpc.jfmpc_239_17

15. Banerjee $P$, Bhattacharya $P$ (2021) Investigating cobalt in soilplant-animal-human system: dynamics, impact and management. J Soil Sci Plant Nutr 21:2339-2354. https://doi.org/10. 1007/s42729-021-00525-w

16. Chasapis CT, Ntoupa PSA, Spiliopoulou CA, Stefanidou ME (2020) Recent aspects of the effects of zinc on human health. Arch Toxicol 94(5):1443-1460. https://doi.org/10.1007/ s00204-020-02702-9

17. FAO/WHO (2004) Vitamin and mineral requirements in human nutrition, 2nd edn. Switzerland, Geneva

18. Governo de Cabo Verde (2002) Resolução - no 344, de 13 de dezembro de 2002, about mandatory of fortification of wheat flour and corn flour with iron and folic acid. Governo de Cabo Verde, Cape Verde.

19. Governo de Cabo Verde (2014) AR (Assembleia da República). Decreto-lei no 39/2014, de 01 de agosto. I Série do Boletim Oficial 46

20. WHO, FAO, UNICEF, GAIN, MI, \& FFI (2009) Recommendations on wheat and maize flour fortification. Meeting Report: Interim Consensus Statement. World Health Organization, Geneva, Switzerland

21. Luzardo OP, del Mar Bernal-Suarez M, Camacho M, HenríquezHernández LA, Boada LD, Rial-Berriel C, ... Díaz-Díaz R (2016) Estimated exposure to EU regulated mycotoxins and risk characterization of aflatoxin-induced hepatic toxicity through the consumption of the toasted cereal flour called "gofio", a traditional food of the Canary Islands (Spain). Food Chem Toxicol 93: 73-81. https://doi.org/10.1016/j.fct.2016.04.022

22. Rubio-Armendáriz C, Paz S, Gutiérrez AJ, Gomes Furtado V, González-Weller D, Revert C, Hardisson A (2021) Toxic metals in cereals in Cape Verde: risk assessment evaluation. Int J Environ Res Public Health 18(7):3833. https://doi.org/10.3390/ ijerph 18073833

23. Rubio-Armendáriz C, Paz S, Gutiérrez ÁJ, González-Weller D, Revert C (2021) Human exposure to toxic metals (Al, Cd, Cr, $\mathrm{Ni}, \mathrm{Pb}, \mathrm{Sr}$ ) from the consumption of cereals in Canary Islands. Foods 10:1158. https://doi.org/10.3390/foods10061158 
24. COMMISSION REGULATION (EC) (2007) COMMISSION REGULATION (EC) No 333/2007 of 28 March 2007 laying down the methods of sampling and analysis for the official control of the levels of lead, cadmium, mercury, inorganic tin, 3-MCPD and benzo(a)pyrene in foodstuffs. Off $\mathbf{J}$ Euro Union L88:29-38

25. Lopes RH, Reid ID, Hobson PR (2007) The two-dimensional Kolmogorov-Smirnov test. XI International Workshop on Advanced Computing and Analysis Techniques in Physics Research 1-12

26. Shin H, Jung Y, Jeong C, Heo JH (2012) Assessment of modified Anderson-Darling test statistics for the generalized extreme value and generalized logistic distributions. Stoch Env Res Risk A 26(1):105-114. https://doi.org/10.1007/s00477-011-0463-y

27. McKnight PE, Najab J (2010) Mann-Whitney U test. In Weiner IB, Craighead WE (ed) The Corsini Encyclopedia of Psychology, $4^{\text {th }}$ edn. John Wiley \& Sons, Inc., New Jersey

28. Croux C, Dehon C (2010) Influence functions of the Spearman and Kendall correlation measures. Stat Methods Appt 19(4):497515. https://doi.org/10.1007/s10260-010-0142-z

29. Paz S, Rubio C, Gutiérrez ÁJ, González-Weller D, Hardisson A (2021) Human exposure assessment to potentially toxic elements (PTEs) from tofu consumption. Environ Sci Pollut Res 28:3352233530. https://doi.org/10.1007/s11356-021-13076-5

30. Rosanoff A, Kumssa DB (2020) Impact of rising body weight and cereal grain food processing on human magnesium nutrition. Plant Soil 457:5-23. https://doi.org/10.1007/s11104-020-04483-7

31. Laskowski W, Górska-Warsewicz H, Rejman K, Czeczotko M, Zwolińska J (2019) How important are cereals and cereal products in the average polish diet? Nutrients 11(3):679. https://doi.org/10. 3390/nu11030679

32. Tejera RL, Luis G, González-Weller D, Caballero JM, Gutiérrez AJ, Rubio C, Hardisson A (2013) Metals in wheat flour; comparative study and safety control. Nutr Hosp 28(2):506-513. https:// doi.org/10.3305/nh.2013.28.2.6287

33. Hernández-Rodríguez L, Afonso-Morales D, Rodríguez-Rodríguez E, Díaz-Romero C (2011) Minerals and trace elements in a collection of wheat landraces from the Canary Islands. J Food Comp Anal 24:1081-1090. https://doi.org/10.1016/j.jfca.2011.04. 016

34. TatahMentan M, Nyachoti S, Scott L, Phan N, Okwori FO, Felemban N, Godebo TR (2020) Toxic and essential elements in rice and other grains from the United States and other countries. Int J Environ Res Public Health 17(21):8128. https://doi.org/10.3390/ ijerph17218128

35. EFSA (European Food Safety Authority). Available online: https://www.efsa.europa.eu/en/microstrategy/food-compositiondata (Accessed 7 May 2021)

36. INSA (Instituto Nacional de Saúde Doutor Ricardo Jorge). Tabela da composição dos alimentos. [Food composition table]. Available online: http://portfir.insa.pt/ Accessed 7 May 2021

37. Bakirciouglu D, Bakircioglu Kurtulus Y, Ibar H (2011) Investigation of trace elements in agricultural soil by BCR sequential extraction method and its transfer to wheat plants. Environ Monit Assess 175:303-314. https://doi.org/10.1007/s10661-010-1513-5

38. Soares JC, Santos CS, Carvalho SM, Pintado MM, Vasconcelos MW (2019) Preserving the nutritional quality of crop plants under a changing climate: importance and strategies. Plant Soil 443(1):1-26. https://doi.org/10.1007/s11104-019-04229-0

39. Šimić D, Zdunić Z, Antun J, Tatjana L, Ivan B, Vinko D, Vlado K (2009) Relations among six micronutrients in grain determined in a maize population. Poljoprivreda (Osijek) 15:1-7

40. Abbaspour N, Hurrel R, Kelishadi R (2014) Review on iron and its importance for human health. J Res Med Sci 19(2):164-174

41. Semedo RM, Santos MM, Baião MR, Luiz RR, da Veiga GV (2014) Prevalence of anaemia and associated factors among children below five years of age in Cape Verde. West Africa J Health Popul Nutr 32(4):646

Publisher's Note Springer Nature remains neutral with regard to jurisdictional claims in published maps and institutional affiliations. 